\title{
Nora Pärr
}

Maximilian Hell und sein wissenschaftliches Umfeld im Wien des 18. Jahrhunderts. Nordhausen: Verlag Traugott Bautz, 2013. Pp. 333. Hb, 70.oo EUR.

Maximilian Hell (1720-92) belongs on any short list of notable late eighteenthcentury Jesuit personalities. Highly regarded during his lifetime as an astronomer, Hell's reputation plummeted decades later when he was wrongly accused of falsifying entries in his log, only to be rehabilitated in 1883 by astronomer Simon Newcomb. Associated with seminal discoveries about the connections between the Finnish and Hungarian languages made in 1769 while he and his fellow Jesuit Joannes Sajnovics were observing a transit of Venus, Hell is recognized as one of the most able Jesuit scientists active at the time of the suppression. His initial interest in, and then debunking of Franz Anton Mesmer's theory of animal magnetism, his flattering cultivation of George III coupled with his refusal to live among Protestants, and his mentoring of younger astronomers of the Habsburg lands make his a complex personality, glimpsed in his smiling, seated portrait in Sami costume (reproduced in this book, along with many other attractive illustrations). Hell's life would make a worthy in-depth biographical study. But this volume is something quite different.

Despite the book's title, Pärr has cast her net much more widely than Hell and his Viennese contemporaries: the reader will encounter Nicholas of Cusa and William of Ockham, as well as scores of other personalities from the sixteenth through twentieth centuries, mostly presented in short, unconnected entries whose common denominators are some relation to both astronomy and Catholic religious life. Hell himself comes into focus only in the final pages, where his will is cited at length and details of his personal relations with peers are captured in a few anecdotes. The question of Hell's Hungarian identity (he was born in what was then Hungary but is also claimed by Slovaks), of great importance to some Hungarian scholars but complicated by his German ancestry and mother tongue, receives only cursory attention. Hell's apparently sincere baroque devotion and his forays into history writing are barely mentioned.

Pärr has combed secondary, and in some cases primary source materials to assemble this collection, although she acknowledges that she has not consulted archives in Hungary or Romania, a possibly significant omission in Hell's case, whose postings as a Jesuit included Cluj. She likewise has not drawn upon Hungarian and Slovak secondary literatures, which include several monographs on Hell. Potentially rich Jesuit archival records and libraries in Rome and elsewhere do not play a significant role in this study. 
One of the book's greatest strengths is its presentation of otherwise largely inaccessible contemporaneous texts, complete with original spellings (see also the delightful memorandum by Maria Theresia on p. 229), describing now lost scientific instruments and structures, and the glimpses it affords of the lives of a few Jesuit brothers who worked as instrument designers and cartographers. Intriguing facts such as the influence of Hell's famed Sami costume on the winter garb of Jesuits in Austria show Pärr's eye for detail. The inclusion of frequently overlooked centers of clerical scientific activity in the Habsburg lands such as Kremsmünster is of particular value for anyone interested in the network of scientists in Catholic religious orders during the Catholic renewal of the eighteenth century.

In the final pages of this collection of biographical entries Pärr offers some analysis of science undertaken by eighteenth-century Catholic clerics, observing that a more mechanistic model of God was widely accepted even among believing Christians. Little additional attention to cultural or intellectual currents is evident elsewhere, although tensions between religious orders are noted. Unfortunately biographical and other facts are sometimes in doubt: James Gregory (1638-1675) was not a monk but a married communicant of the Anglican church, Rajhrad (not Rajhard) is in Moravia, not Hungary, the surnames of two noted Jesuits are Strnad, not Strnadt, and Makó, not Macko, and Hell's healthy-looking "death mask" reproduced among the illustrations is dated 1769 , some twenty-three years before his death. Despite these errors Pärr's book will be of value to those seeking hard to locate biographical data on the lesser-known personalities of early modern science, although without an index, chronological or geographical organization, the reader will have to hunt for names. This study does not reframe questions about the scientific cultures of Enlightenment Europe or propose startling new interpretations, but it will aid scholars in doing both these things through its copious and carefully assembled source references.

\section{Paul Shore}

University of Manitoba shorep@brandonu.ca 